\title{
PRINSIP KEADILAN DAN KESEIMBANGAN DALAM PENENTUAN NILAI TUKAR BARANG (HARGA) PERSPEKTIF ISLAM DAN HUKUM PERLINDUNGAN KONSUMEN
}

\author{
Iffaty Nasyi’ah \\ Fakultas Syariah UIN Maulana Malik Ibrahim Malang \\ Iffaty.nasyiah@gmail.com
}

\begin{abstract}
The Law No. 8 of 1999 about Consumer Protection Article 4 letter b said that one of consumer rights, namely the right to select and obtain goods in accordance with the exchange rate. Not found in authentic explanation regarding this exchange rate, if the exchange rate is the exchange rate that is in accordance with the agreement between the seller and the buyer, or in accordance with the production values or the exchange rate that corresponds to the price market, this then raises the question of free interpretation among the businessmen that the exchange rate is determined only by the desire of businessmen and weighing of benefits desired by businesses alone, so that entrepreneurs are allowed to set the exchange rate goods many times from the value of its production. In Islamic law is not found the rules regarding the determination of the limits of this exchange rate, but Islam is a tolerant religion, including in determining the exchange rate as the words of the Prophet Muhammad: "May Allah have mercy to a tolerant person (easy) when it sells, tolerant when buying, tolerant when fulfilling the obligation and tolerant when claiming its rights". (HR. Bukhari from Jabir)

Undang-undang Nomor 8 Tahun 1999 Tentang Perlindungan Konsumen pasal 4 huruf $b$ mengatur mengenai salah satu hak konsumen yaitu hak untuk memilih dan mendapatkan barang yang sesuai dengan nilai tukarnya. Tidak ditemukan penjelasan otentik dalam UUPK mengenai nilai tukar ini, apakah nilai tukar yang dimaksud adalah nilai tukar yang sesuai dengan kesepakatan antara penjual dan pembeli, atau yang sesuai dengan nilai produksi ataukah nilai tukar yang sesuai dengan harga pasar, pertanyaan ini kemudian memunculkan interpretasi bebas di kalangan pelaku usaha bahwa nilai tukar itu hanya ditentukan oleh keinginan pelaku usaha dengan pertimbangan keuntungan yang diinginkan oleh pelaku usaha saja, sehingga pelaku usaha dibolehkan menetapkan nilai tukar barangnya berkali-kali lipat dari nilai produksinya. Dalam hukum Islam memang tidak ditemukan aturan mengenai batas penetapan nilai tukar ini, tetapi Islam adalah agama yang toleran, termasuk dalam menentukan nilai tukar ini sebagaimana sabda Rasulullah SAW: "Semoga Allah SWT merahmati orang yang toleran (gampang) ketika menjual, toleran ketika membeli, toleran ketika menunaikan kewajiban dan toleran ketika menuntut hak". (HR. Bukhari dari Jabir)
\end{abstract}

Kata Kunci : Perlindungan konsumen, hak konsumen, nilai tukar, hukum Islam

Undang-undang Nomor 8 Tahun 1999 Tentang Perlindungan Konsumen (selanjutnya disebut UUPK) telah diberlakukan sejak tahun 2000 yaitu satu tahun setelah disahkannya. Tujuan utama dibentuknya UUPK ini adalah untuk meningkatkan iklim usaha yang kondusif yang sesuai dengan perkembangan dunia usaha itu sendiri. Selain itu, UUPK dibentuk sebagai upaya untuk melindungi konsumen dari tindakan sewenang-wenang pelaku usaha yang 
justru karena pesatnya perkembangan dunia usaha menyebabkan pelaku usaha melakukan segala tindakan yang dianggap dapat meningkatkan keuntungan yang sebesarbesarnya. Dengan meraih keuntungan yang besar, maka mereka mempunyai modal untuk membuka usaha baru lagi. Demikian seterusnya sehingga pemilik modal semakin kaya dan yang tidak memiliki modal akan semakin terpuruk. ${ }^{1}$

Sosialisasi dan penjelasan kepada masyarakat mengenai UUPK ini masih minim, hal ini dapat terlihat dari penjelasan otentik yang diberikan UUPK itu sendiri. Banyak pasal yang membutuhkan penjelasan, namun dalam penjelasannya hanya disebutkan "cukup jelas". Sebagai misal dalam pasal 4 huruf b yang berbunyi : "Hak Konsumen adalah : "hak untuk memilih barang dan/atau jasa serta mendapatkan barang dan/atau jasa tersebut sesuai dengan nilai tukar dan kondisi serta jaminan yang dijanjikan"'. Pasal ini tidak memberikan definisi mengenai nilai tukar, apakah yang dianggap "nilai tukar" itu adalah harga yang telah disepakati antara penjual dan pembeli, ataukah yang dimaksud dengan "nilai tukar" itu adalah harga yang pantas yang dihitung dari nilai produksi atau harga yang sesuai dengan harga pasar. Hal ini penting untuk dikaji mengingat banyaknya kasus mengenai nilai tukar ini. Pelaku usaha menentukan nilai tukar sesuai dengan perhitungan keuntungan yang diinginkannya. Adagium lama yang menyatakan bahwa "pembeli adalah raja" menjadi terbalik dan justru pelaku usahalah yang menjadi raja dalam menentukan kemenangan sebuah pertarungan tawar-menawar harga sebuah produk. Sedangkan konsumen sebagai pihak yang membutuhkan diposisikan sebagai pihak yang kalah dan harus membayar dengan harga yang telah ditentukan oleh pelaku usaha. Harga properti, harga pakaian, harga bahan pokok, dan lain-lain menjadi berkali-kali lipat dari harga produksinya. Masalah bisa muncul ketika pada satu kesempatan seseorang membeli barang di suatu tempat dan kemudian menemukan bahwa di tempat lain harga barang yang sama jauh lebih murah dan sesuai dengan harga di pasaran. Jika dikatakan bahwa nilai

\footnotetext{
1 Peristiwa demikian yang harus dihindari karena dapat memperkuat akar kapitalisme
}

tukar barang adalah nilai tukar yang sesuai dengan harga pasar, maka pada kasus ini konsumen dapat melakukan komplain kepada penjual karena nilai tukar yang terlalu tinggi.

Carefour melakukan pengembalian dua kali lipat dari selisih harga jika konsumen menemukan harga yang lebih murah dari harga yang ditetapkan oleh Carefour ${ }^{2}$. Tetapi tidak semua pelaku usaha melakukan hal yang serupa dengan yang dilakukan oleh Carefour tersebut. Manajemen pemasaran yang dilakukan oleh Carefour ini menunjukkan bahwa nilai tukar atau harga ini sangatlah sensitif dalam menentukan hasrat beli konsumen.

Beberapa waktu yang lalu, pemerintah dan masyarakat disibukkan oleh ulah para tengkulak yang menaikkan harga bahan pokok melebihi harga tertinggi yang pernah ada. Bawang putih mencapai 50 ribu per $\mathrm{kg}$, cabai merah mencapai harga 80 ribu per $\mathrm{kg}$ dan cabai rawit mencapai harga 100 ribu per kg. Kondisi seperti ini tidak serta merta memainkan peran pemerintah untuk campur tangan dalam menentukan harga bahan pokok ini dan menindak para pelaku usaha yang menaikkan harga yang terlalu tinggi (overpricing). Mekanisme pasar, yang sesungguhnya dimotori oleh para tengkulak (pelaku usaha) memegang peran utama dalam melambungkan harga bahan pokok, sedangkan konsumen hanya mengikuti ritme harga yang ada.

Pemerintah mempunyai fungsi mengatur masyarakatnya. Hal ini seringkali diwujudkan dalam fungsi pengawasan. Ketika harga bahan pokok melambung, pemerintah melakukan operasi pasar. Pemerintah tidak mengambil peran mengatur dengan menentukan harga bahan pokok atau harga barang-barang yang sangat dibutuhkan oleh masyarakat. Hal demikian menyebabkan para pelaku usaha bersaing sendiri antar pelaku usaha. Harga ditentukan oleh mekanisme pasar, dimana ketika permintaan tinggi dan jumlah produksi hanya sedikit, maka harga menjadi tinggi dan begitupun sebaliknya. Demo buruh terjadi hampir setiap tahun menuntut kenaikan gaji karena dari gaji yang telah ditetapkan oleh pemerintah melalui UMK/UMR masih tidak mencukupi untuk kebutuhan sehari-hari yang

\footnotetext{
${ }^{2}$ Dengan syarat dan ketentuan yang berlaku
} 
semakin lama semakin melambung. Kenaikan UMK/UMR justru membuat harga yang diproduksi oleh suatu perusahaan menjadi naik dan konsekwensi akhirnya kembali kepada buruh itu sendiri yang notabene adalah masyarakat kelas bawah.

Hukum Islam tidak menentukan batas keuntungan yang boleh diambil dalam sebuah perdagangan. Dalam satu riwayat diceritakan : "Sahabat Urwah diberi uang satu dinar oleh Rasulullah SAW untuk membeli seekor kambing. Kemudian dia membeli dua ekor kambing dengan harga satu dinar, ketika dia menuntun dua ekor kambing itu, tiba-tiba seorang lelaki menghampirinya dan menawar kambing tersebut, maka ia menjual dengan harga satu dinar. Kemudian ia menghadap Rasulullah SAW dengan membawa satu dinar uang dan satu ekor kambing. Beliau lalu meminta penjelasan dan ia ceritakan kejadiannya, maka beliaupun berdo'a: "Ya Allah berkatilah Urwah dalam bisnisnya"," 3 Dari riwayat ini dapat diambil kesimpulan mengenai bolehnya mengambil keuntungan sampai $100 \%$ atau dua kali dari modal yang dikeluarkan.

Islam adalah agama yang penuh kasih sayang, toleransi dan kebersamaan dalam segala sisi kehidupan, termasuk dalam bisnis atau perdagangan. Rasulullah SAW bersabda : "semoga Allah SWT merahmati orang yang toleran (gampang) ketika menjual, toleran ketika membeli, toleran ketika menunaikan kewajiban dan toleran ketika menuntut hak" (HR. Bukhari dari Jabir). Dari uraian diatas ada dua hal yang dapat diambil sebagai permasalahan mengenai nilai tukar ini, yaitu : Bagaimana UUPK dan Islam memaknai "nilai tukar" ini ? dan bagaimana peran pemerintah dalam mengatur mengenai "nilai tukar"?

\section{Nilai Tukar Barang Dalam Hukum Perlindungan Konsumen}

Konsumen adalah setiap orang pemakai barang dan/atau jasa yang tersedia dalam masyarakat, baik bagi kepentingan diri sendiri, keluarga, orang lain maupun makhluk hidup

\footnotetext{
${ }^{3}$ Riwayat Imam Ahmad dalam musnadnya (IV/376), Bukhari dalam Fathul Bari (VI/632), Abu Dawud (no.3384), Tirmidzi (no. 1258), dan Ibnu Majah (no.2402) dari penuturan Urwah Ibnul Ja'd al-Bariqi ra.
}

lain dan tidak untuk diperdagangkan. ${ }^{4}$ Dalam penjelasan pasal 1(2) UUPK, dinyatakan bahwa dalam kepustakaan ekonomi dikenal konsumen akhir dan konsumen antara. Konsumen Akhir adalah pengguna atau pemanfaat akhir dari suatu produk, sedangkan konsumen antara adalah konsumen yang menggunakan suatu produk sebagai bagian dari suatu proses produksi suatu produk lainnya. Yang dimaksud konsumen dalam UUPK adalah konsumen akhir, sedangkan konsumen antara masuk dalam kategori pelaku usaha.

Perlindungan konsumen adalah segala upaya yang menjamin adanya kepastian hukum untuk memberi perlindungan kepada konsumen. Dalam rumusan pengertian ini, kalimat "segala upaya menjamin kepastian hukum", merupakan benteng peniadaan kesewenang-wenangan yang merugikan pelaku usaha untuk melindungi kepentingan konsumen dalam suatu transaksi. Dalam hal ini, bukan berarti kepentingan pelaku usaha tidak menjadi perhatian hukum, karena keberadaan perekonomian nasional banyak ditentukan oleh para pelaku usaha. ${ }^{5}$ Kesewenang-wenangan akan mengakibatkan ketidakpastian hukum. Oleh karena itu, sudah seharusnya setiap peraturan dapat dimaknai dengan jelas termasuk dalam UUPK ini sehingga tujuannya dapat tercapai. Hal ini menjadi tugas pemerintah sebagai pembuat undang-undang dibantu oleh para akademisi untuk mensosialisasikan peraturan tersebut dan menjelaskan mengenai hal-hal yang dianggap kurang jelas.

Dimana ada hak disitu ada kewajiban. Hak konsumen dalam UUPK berarti kewajiban bagi pelaku usaha terhadap konsumen atau kewajiban konsumen kepada pelaku usaha. Mengenai hak konsumen untuk mendapatkan haknya dalam memilih dan mendapatkan barang yang sesuai dengan nilai tukarnya, maka disitu ada kewajiban bagi pelaku usaha untuk memberikan barang tersebut sesuai dengan nilai tukarnya. Hal ini dinyatakan dalam pasal 5 huruf c yang menyatakan : "Kewajiban konsumen adalah membayar sesuai dengan nilai tukar yang disepakati”.

\footnotetext{
${ }^{4}$ UUPK pasal 1 angka 2

${ }^{5}$ Ahmad Miru dan Sutarman Yodo, Hukum Perlindungan Konsumen, (Jakarta : PT Raja Grafindo Persada, 2007), h. 1-2
} 
Dalam pasal 6 huruf a mengenai hak pelaku usaha juga dinyatakan bahwa : "Hak pelaku usaha adalah : hak untuk menerima pembayaran yang sesuai dengan kesepakatan mengenai kondisi dan nilai tukar barang dan/atau jasa yang diperdagangkan". Dari kedua pasal tersebut dapat dikatakan bahwa nilai tukar barang yaitu harga yang telah disepakati antara konsumen dan pelaku usaha. Pada saat konsumen membayar suatu barang maka disitu dianggap bahwa nilai tukar atau harga barang tersebut telah sesuai karena telah terjadi kesepakatan antara penjual dan pembeli. Tidak dipermasalahkan ketika harga tersebut ternyata lebih tinggi dari harga rata-rata di pasaran, karena kesepakatan harga ini menjadi syarat utama dalam transaksi jual-beli. Apabila ketika dalam menentukan harga tersebut (dalam proses tawar-menawar) terjadi penipuan atau penyesatan, maka disini konsumen dapat menuntut pembatalan transaksi. Apakah konsumen dapat menuntut jika di tempat lain harga barang tersebut ternyata jauh lebih murah atau sesuai dengan harga pasar dan konsumen baru menyadarinya ? apakah kejadian ini menjadi sah dalam hukum UUPK karena telah terjadi kesepakan harga sebagaimana dimaksud oleh pasal 5 huruf $\mathrm{c}$ dan pasal 6 huruf a di atas?

Pasal 7 UUPK menjelaskan mengenai kewajiban pelaku usaha terhadap konsumen, namun dalam pasal ini tidak disebut mengenai nilai tukar barang. Nilai tukar barang hanya diatur dalam pasal 4 huruf $\mathrm{b}$ (mengenai hak konsumen), pasal 5 huruf c (mengenai kewajiban konsumen) dan pasal 6 huruf a (mengenai hak pelaku usaha). Dengan demikian, masih terlihat adanya ketimpangan dalam membahas mengenai nilai tukar barang ini. Dikatakan bahwa pelaku usaha mempunyai hak untuk mendapatkan nilai tukar yang sesuai dengan kesepakatan ${ }^{6}$, namun dalam UUPK, pelaku usaha tidak dibebani dengan kewajiban untuk menentukan nilai tukar yang sesuai atau mempunyai standar, dalam arti sesuai (disesuikan) dengan harga produksi dan atau sesuai dengan harga pasar yang berlaku.

Pasal 1320 KUH Perdata mengatur mengenai syarat sahnya suatu perjanjian,

\footnotetext{
${ }^{6}$ Pasal 6 huruf a
}

yaitu : 1). Adanya kesepakatan, 2). cakap hukum, 3). mengenai suatu hal tertentu dan 4). causa yang halal. Pasal 6 huruf a telah sesuai dengan pasal 1320 KUH Perdata ini (khususnya mengenai syarat yang kesatu), dengan demikian akan menjadi sah segala harga yang ditetapkan oleh pelaku usaha asalkan konsumen menyepakati harga tersebut. Harga kendaraan bermotor, harga properti dan lain sebagainya yang melambung tinggi juga akan menjadi sah jika konsumen menyepakatinya, asalkan tidak ada unsur penyesatan, penipuan dan pemaksaan (dwang, dwaling, bedrog).

Kesepakatan mengenai harga antara pelaku usaha dan konsumen sebagaimana diatas dianggap sebagai suatu perjanjian atau kontrak yang tidak tertulis. Dalam ranah keperdataan, suatu kontrak harus dilaksanakan dengan itikad yang baik sebagaimana diatur dalam pasal 1338 KUH Perdata. Pelaku usaha yang tidak menetatapkan harga dengan tidak sewajarnya pastilah tidak memenuhi unsur itikad baik ini. Unsur itikad baik ini dalam bahasa Belanda disebut "tegoeder trouw", dan dalam bahasa Inggris disebut "in good faith" asas ini adalah asas yang terpenting dalam sebuah perjanjian yang dalam konteks ini adalah dasar dari hubungan yang baik antara pelaku usaha dan konsumen. Pasal 1339 KUH Perdata berbunyi "perjanjian tidak mengikat untuk hal yang dengan tegas dinyatakan didalamnya, tetapi juga untuk segala sesuatu yang menurut sifat perjanjian itu diharuskan oleh kepatutan, kebiasaan atau undang-undang”. Kepatutan dan kebiasaan dalam konteks harga ini dapat dimaknai kesesuaian dengan harga pasar. Harga adalah harga yang patut yaitu didasari oleh norma-norma yang ada serta yang sesuai dengan kebiasaan (di suatu tempat dan di suatu kalangan tertentu).

Hukum perlindungan konsumen didasarkan atas beberapa prinsip, diantaranya adalah prinsip keseimbangan dan keadilan. Prinsip keseimbangan dimaksudkan untuk memberikan keseimbangan antara kepentingan konsumen, pelaku usaha, dan pemerintah dalam arti materiil ataupun spiritual. $^{7}$ Dibentuknya undang-undang perlindungan konsumen pada intinya adalah untuk menciptakan

7 Penjelasan pasal 2 UU Nomor 8 Tahun 1999 Tentang Perlindungan Konsumen 
keseimbangan ini. Selain faktor lemahnya kesadaran konsumen untuk menuntut haknya serta rendahnya pengetahuan konsumen akan kualitas barang atau produk yang dihasilkan oleh pelaku usaha, prinsip keseimbangan ini juga diterapkan untuk menumbuhkan sikap jujur dan tanggungjawab pelaku usaha terhadap konsumen. Hal ini disebabkan pada dasarnya pelaku usaha masih memegang prinsip utama dalam ranah ekonomi: "dengan modal seminimal mungkin, mendapatkan keuntungan semaksimal mungkin". Dengan demikian prinsip keseimbangan ini juga diharapkan menjadi prinsip dalam penentuan nilai tukar barang atau harga. Harga haruslah seimbang antara nilai produksi dan harga jualnya.

Prinsip keadilan dimaksudkan agar partisipasi seluruh rakyat dapat diwujudkan secara maksimal dan memberikan kesempatan kepada konsumen dan pelaku usaha untuk memperoleh haknya dan melaksanakan kewajibannya tersebut. ${ }^{8}$ Undang-undang perlindungan konsumen tidak hanya diharapkan menjadi payung hukum bagi perlindungan konsumen di Indonesia, namun lebih jauh lagi undang-undang perlindungan konsumen harus dapat menjadi acuan bagi peraturan perundangan lainnya dalam bidang perlindungan konsumen. Misalnya, pengintegrasian undang-undang perlindungan konsumen ke dalam undang-undang perbankan, lingkungan hidup, perusahaan, pasar modal, lalu lintas, kesehatan, pendidikan, dan lain sebagainya. Dengan demikian, perlindungan terhadap hak-hak konsumen tidak lagi dilaksanakan secara parsial, namun dilaksanakan secara terpadu, utuh, dan universal. ${ }^{9}$ Hal ini dapat terlaksana dengan baik dengan partisipasi seluruh rakyat, termasuk pelaku usaha dan konsumen. Pelaku usaha melakukan kewajiban terhadap konsumen dan begitu juga sebaliknya, sehingga masingmasing pihak sama-sama mendapatkan haknya. Dalam penentuan harga, prinsip keadilan dimaksudkan agar pelaku usaha menetapkan harga sesuai dengan nilai tukar secara proporsional, tidak terlalu tinggi dan juga tidak terlalu rendah, bahkan diharapkan mempunyai

\footnotetext{
8 Penjelasan pasal 2 UU Nomor 8 Tahun 1999 Tentang Perlindungan Konsumen

${ }^{9}$ Zulham, Hukum Perlindungan Konsumen (Jakarta: Prenada Media Group, 2013), h. 70
}

standar yang pasti dari nilai produksi yang telah dikeluarkan. Dengan demikian konsumen mendapatkan harga secara adil, dalam adil secara proporsional.

\section{Nilai Tukar Barang Dalam Perspektif Islam}

Dalam perspektif Islam, pada dasarnya dalam sebuah perniagaan mengambil keuntungan berapapun tidak dibatasi, asalkan unsur kerelaan (suka sama suka) telah terpenuhi. Allah SWT berfirman dalam surat an-Nisa ayat 29 yang berbunyi :

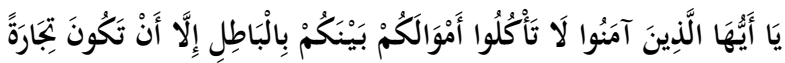

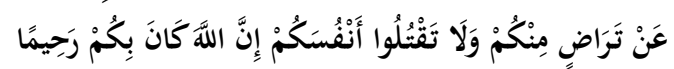

Artinya : "Hai orang-orang yang beriman, janganlah kamu saling memakan harta sesamamu dengan jalan yang batil, kecuali dengan jalan perniagaan yang berlaku suka sama suka di antara kamu. Dan janganlah kamu membunuh dirimu, sesungguhnya Allah adalah Maha Penyayang kepadamu”.

Bisnis atau perdagangan harus dilandasi dengan nilai-nilai dan etika yang menjunjung tinggi kejujuran dan keadilan. Rasulullah SAW menunjukkan kesuksesan dalam perdagangan ketika membawa barang dagangan milik Khadijah binti Khuwailid. Kesuksesan Rasulullah SAW saat itu ditandai dengan banyaknya penduduk Mekkah maupun diluar Mekkah yang membeli produk yang dibawa oleh beliau. Keuntungan yang didapatkan Khadijah melalui Rasulullah SAW ini lebih banyak dibandingkan dengan yang lain. Rasulullah SAW menunjukkan reputasi yang baik karena berbasis kejujuran dan keadilan dalam berbisnis.

Berkenaan dengan masalah keadilan, nashnash dalam al-Qur'an yang menyebutkan tentang keadilan, bukan hanya sekedar anjuran, namun berbentuk perintah yang bersifat mutlak tanpa ikatan waktu, tempat atau individu tertentu. ${ }^{10}$ Dalam kaitannya dengan bisnis atau perdagangan, maka perintah keadilan ini ditujukan kepada seluruh masyarakat termasuk di dalamnya para pelaku usaha dan konsumen. Allah SWT berfirman dalam surat an-Nahl ayat 90 yang berbunyi :

\footnotetext{
${ }^{10}$ A. Kadir, Hukum Bisnis Syariah Dalam Al-Quran (Jakarta : Sinar Grafika Offset, 2010), h. 76
} 
122 | de Jure, Jurnal Syariah dan Hukum, Volume 6 Nomor 2, Desember 2014 hlm. 117-127

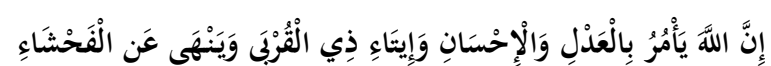
وَالْمُنْكِرِ وَالْبَغْيَ

Artinya : "Sesungguhnya Allah menyuruh kamu berlaku adil dan berbuat kebajikan, memberi kepada kamu kerabat, dan Allah melarang dari perbuatan keji, kemungkaran dan permusuhan".

Sedangkan dalam transaksi bisnis, prinsip keadilan termaktub dalam firman Allah surat ar-Rahman ayat 9 yang berbunyi:

$$
\text { وَأَقِيمُوا الْوَزْنَ بِالْقِسنطِ وَلَا تُخِْسرُوا الْمِيزَانَ }
$$

Artinya : "dan tegakkanlah timbangan itu dengan adil dan janganlah kamu mengurangi neraca itu”.

Juga firman Allah dalam surat al-Isra' ayat 35 yang berbunyi :

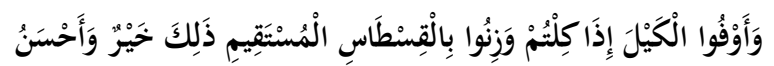

Artinya : "dan sempurnakanlah takaran apabila kamu menakar, dan timbanglah dengan neraca yang benar. Itulah yang lebih utama (bagimu) dan lebih baik akibatnya".

Allah SWT menyuruh manusia agar menyempurnakan takaran dan melarang curang dalam menakar. Secara majazi, makna neraca atau takaran itu menunjukkan bahwa segala sesuatu itu harus dilakukan secara seimbang, selaras dan adil. Begitupun dalam masalah bisnis, khususnya dalam menetapkan nilai tukar barang atau harga. Tidaklah dapat dikatakan seimbang, selaras atau bahkan adil jikalau pelaku usaha dalam menetapkan harga terlalu tinggi dan memberatkan konsumen.

Lebih jauh, ${ }^{11}$ al-Qur'an mengisahkan tentang suatu kaum yang berbuat curang dalam transaksi bisnis sekaligus menyimpang dari nilai keadilan dalam hal takaran dan timbangan. Mereka mengurangi sesuatu yang menjadi hak konsumen. Lalu Allah mengirim seorang rasul untuk mengembalikan mereka ke jalan keadilan dan memperbaikinya. Mereka adalah penduduk Aikah (Madyan) kaum nabi Syuaib AS yang telah diperingatkan Allah melalui firman-Nya dalam surat asy-Syu'ara ayat $181-183$ yang berbunyi :

\footnotetext{
${ }^{11}$ A. Kadir, Hukum, h. 82
}

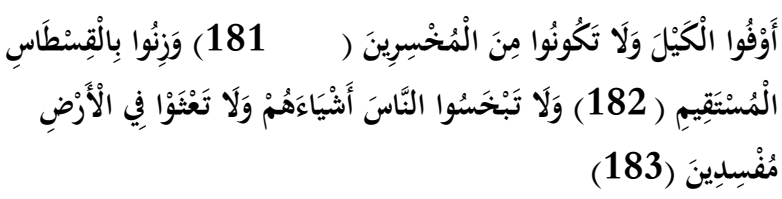

Artinya: "Sempurnakanlah takaran dan janganlah kamu termasuk orang-orang yang merugikan; dan timbanglah dengan timbangan yang lurus. Dan janganlah kamu merugikan manusia pada hak-haknya".

Mengenai nilai tukar barang atau harga, Islam sesungguhnya tidak memberikan batasan yang pasti berapa keuntungan yang boleh diambil oleh pelaku usaha, asal dari mencari keuntungan itu disyariatkan, kecuali apabila dilakukan dengan cara-cara yang bertentangan dengan syara'. ${ }^{12}$ Soal keuntungan dalam usaha bisnis ini tidak ada standarisasinya, baik bersifat minimal maupun maksimal. Yusuf alQardlawi menulis, "saya menemukan indikasi bahwa laba atau keuntungan apabila selamat dari sebab-sebab dan praktik-praktik keharaman, maka hal itu diperbolehkan dan dibenarkan syara' hingga si pelaku usaha dapat memperoleh laba sebesar $100 \%$ dari modal (pembeliannya) bahkan beberapa kali lipat ${ }^{13}$ (beberapa ratus persen)". ${ }^{14}$ Diperbolehkannya mengambil keuntungan sampai $100 \%$ ini berdasarkan hadis yang menceritakan tentang Urwah sebagaimana diatas. Namun jika dihubungkan dengan hadis yang diriwayatkan oleh Bukhari dari Jabir yang berbunyi :"Rasulullah bersabda : "Semoga Allah SWT merahmati orang yang toleran (gampang) ketika menjual, toleran ketika membeli, toleran ketika menunaikan kewajiban dan toleran ketika menuntut hak",", dapat diartikan semakin kecil keuntungan yang diambil oleh pelaku usaha maka semakin besar toleransinya terhadap konsumen dan Allah SWT merahmati bisnis pelaku usaha ini. Pelaku usaha yang mengambil keuntungan yang kecil, maka perputaran usahanya semakin cepat dan justru

\footnotetext{
${ }^{12}$ A. Kadir, Hukum, h. 116

13 Zubair bin 'Awwam salah seorang dari sepuluh sahabat yang dijamin masuk surga. Dimana Ia pernah membeli sebidang tanah di daerah 'Awwali Madinah dengan harga 170.000 , kemudian dijualnya dengan harga 1.600.000, ini artinya sembilan kali lipat dari harga belinya. (Shahih al-Bukhari, nomor 3129)

${ }^{14}$ Yusuf al-Qardlawi, , Fatwa-Fatwa Kontemporer 2 (Hadyu al-Islam; Fatawi Muasyirah), penerjemah As'ad Yasin (Jakarta : Gema Insani Press, 1995), h. 579
} 
dapat mempercepat margin keuntungannya. Imam al-Ghazali dalam Ihya' Ulumuddinnya $(\mathrm{II} / 72)^{15}$ menganjurkan perilaku ihsan dalam berbisnis sebagai sumber keberkahan, yakni mengambil keuntungan rasional yang lazim berlaku dalam bisnis tersebut di tempat itu. Ini berarti harga yang pantas adalah harga yang sesuai dengan harga pasar, yang notabene bersifat rasional dan tidak terlalu tinggi.

Cerita mengenai Rasulullah SAW ketika menjalankan bisnis Khadijah binti khuwailid menunjukkan bahwa harga ditentukan secara independen antara pelaku usaha dan konsumen tanpa ada campur tangan, intervensi ataupun paksaan dari siapapun. Dari sini muncullah harga yang sepatutnya dengan bekerjanya penawaran dan permintaan. Inilah yang kemudian disebut dengan mekanisme pasar. Bagaimana mekanisme pasar yang dikehendaki oleh Islam ? dikatakan oleh Muhammad Nejatullah Siddiqi ${ }^{16}$ mekanisme pasar yang dikehendaki oleh Islam mempunyai dua asumsi yaitu rasionalitas ekonomi dan persaingan sempurna. Berdasarkan asumsi ini, sistem pasar di bawah pengaruh semangat Islam dapat dianggap sempurna. Sistem ini menggambarkan keselarasan antara kepentingan para konsumen.

Rasionalitas ekonomi mengandung makna bahwa konsumen dan produsen (pelaku usaha) dapat memaksimumkan kepuasan masingmasing. Kepuasan tersebut akan diusahakannya secara bertahap (tetap dan berkesinambungan). Untuk itu, konsumen dan produsen dapat mengetahui dengan jelas apa dan bagaimana keputusan yang harus diambil dalam pemenuhan kepuasan ekonomi tersebut. Sedangkan yang dimaksud dengan persaingan sempurna adalah pasar dimana kondisi pasar kompetitif dan terbuka serta mendorong segala sesuatunya menjadi persaingan yang sehat dan adil, suka sama suka. ${ }^{17}$ Tujuan persaingan sempurna ini agar melahirkan sebanyak

15 Veithzal Rivai dkk., Islamic Business And Economic Ethics, Mengacu Pada Al-Qur'an Dan Mengikuti Jejak Rasulullah SAW dalam Bisnis, Keuangan dan Ekonomi (Jakarta : PT Bumi Aksara, 2012), h. 273

${ }^{16}$ Suhrawardi K Lubis dan Farid Wajdi, Hukum Ekonomi Islam (Jakarta : Sinar Grafika Offset, 2012), h. 23

${ }^{17}$ Lukman Hakim, Prinsip-Prinsip Ekonomi Islam (tt : Erlangga, 2012), h. 172 mungkin konsumen dan produsen di pasar, sehingga barang yang ada bersifat heterogen, dan faktor produksi dapat bergerak bebas.

\section{Peran Pemerintah Dalam Menentukan Nilai Tukar Barang}

Undang-undang Perlindungan Konsumen dibuat untuk melindungi konsumen dari kesewenang-wenangan pelaku usaha yang seringkali hanya berorientasi pada keuntungan. Memang hanya sebagian kecil dari pelaku usaha yang berada pada koridor ini, namun, bisa jadi mereka justru dapat mempengaruhi harga pasar. Sebagian pelaku usaha menetapkan harga yang terlalu tinggi bukan karena sedikitnya produk di pasar atau banyaknya permintaan konsumen tetapi lebih daripada itu mereka menetapkan harga yang tinggi karena mereka mempunyai modal yang besar dan hanya merekalah yang mampu memproduksi barang tersebut. Sebagai misal adalah harga perumahan (properti). Rumah adalah kebutuhan dasar (primer) manusia, sehingga manusia dengan berbagai cara akan mewujudkan rumah tersebut. Di sisi lain, harga rumah semakin tinggi karena developer (yang notabene dapat dihitung dengan jari jumlahnya) menetapkan demikian. Tidak ada patokan mengenai harga tertinggi dalam bisnis properti ini. Undang-undang Perlindungan Konsumen tidak mengatur mengenai penetapan harga yang tinggi (overpricing) oleh pelaku usaha, padahal overpricing ini menodai penegakan hukum perlindungan konsumen. Konsumen dalam posisi ini pasti merasa tidak dihargai haknya untuk mendapatkan nilai tukar yang wajar. Seharusnya, konsumen dapat melakukan komplain $^{18}$ kepada pelaku usaha minimal dengan maksud agar pelaku usaha tidak menetapkan harga yang terlalu tinggi. Asas keseimbangan menunjukkan pula bahwa dalam penegakan hukum perlindungan konsumen,

${ }^{18}$ Komplain adalah wujud ketidakpuasan konsumen atas barang atau jasa yang diberikan oleh pelaku usaha yang dilakukan dengan beberapa cara, seringkali dilakukan dengan mengungkapkan secara langsung ketidakpuasan tersebut kepada pelaku usaha. Ada berbagai macam tujuan konsumen melakukan komplain ini, diantaranya adalah memberi peringatan kepada pelaku usaha agar tidak berbuat hal yang sama, meminta ganti kerugian, atau meminta kembali uang yang telah dibayarkan oleh konsumen dengan mengembalikan barang yang sudah dibeli. 
harus ada keseimbangan peran antara tiga pihak; yaitu konsumen, pelaku usaha dan pemerintah. Keseimbangan peran ini diwujudkan dalam tata kerjasama yang jelas, sehingga jika salah satu peran tidak dimainkan, maka tegaknya hukum perlindungan konsumen ini tidak akan terwujud.

Diatas telah dibahas mengenai nilai tukar yang hanya ditentukan oleh pelaku usaha, namun belum dibicarakan penentuan nilai tukar yang dapat dipengaruhi oleh pemerintah. Nilai tukar selalu muncul berdasarkan rumus ekonomi yang tertua ${ }^{19}$, yaitu dimana permintaan tinggi, maka nilai tukar akan tinggi pula, begitu pun sebaliknya. Namun, kenyataan di lapangan menunjukkan bahwa campur tangan pemerintah dalam mempengaruhi nilai tukar ini sangat diperlukan, sehingga nilai tukar tidak melonjak tinggi dan melemahkan daya beli masyarakat atau sebaliknya tidak jatuh sehingga merugikan pelaku usaha. Naik dan turunnya harga ini seringkali disebabkan adanya distorsi dalam pasar. Dalam rumus ekonomi yang dikemukakan oleh Adam Smith tersebut, kegagalan pasar dapat terjadi, dan salah satu faktornya dikarenakan adanya distorsi tersebut. Disinilah diperlukan intervensi dari pemerintah. Intervensi pemerintah dapat berupa operasi pasar sebagai bentuk pengawasan dan menentukan Harga Eceran Tertinggi (Ceiling Price) sebagai bentuk pengaturan atau regulasi. Bentuk intervensi pemerintah dalam ekonomi mikro adalah kontrol harga. Tujuan kontrol harga adalah untuk melindungi konsumen atau produsen. Bentuk kontrol harga yang paling umum digunakan adalah penetapan harga dasar (floor price) dan harga maksimum (ceiling price). ${ }^{20}$

Ada 2 cara Intervensi Pemerintah dalam penetapan harga: Pertama, Intervensi Pemerintah secara Langsung: (1) Penetapan Harga Minimum (floor price). Harga minimum atau harga dasar merupakan batas seberapa rendah harga dapat dikenakan pada suatu produk melalui kesepakatan bersama atau ketentuan pemerintah. Penetapan harga

\footnotetext{
${ }^{20}$ Sigit Satrio, Penetapan Harga (Ceiling Price dan Floor Price) (Online), (http://satriasig.blogspot.com/2011/11/penetapan-harga-ceilingprice-dan-floor.html. Diakses 18 Mei 2014)
}

minimum atau harga dasar yang dilakukan oleh pemerintah bertujuan untuk melindungi produsen, terutama untuk produk dasar pertanian. Kebijakan harga dasar dapat biasa digunakan pada saat ditemukan kapasitas produksi di pasar terlalu sedikit sehingga kuantitas barang beredar di pasar lebih rendah dari permintaan pasar, hal ini dikarenakan terlalu rendah nya harga jual yang ada di pasar, sehingga selisih harga produksi dengan harga jual pasar terlalu kecil. Hal ini menyebabkan produsen takut untuk memperbanyak kapasitas produksi dikarenakan harga jual yang rendah dan supplier cenderung menyimpan barang mereka menunggu harga pasar pulih kembali. Oleh karena itu dalam situasi seperti ini pemerintah biasanya menetapkan harga dasar. Harga dasar yang ditetapkan akan berada di atas harga equilibrium pasar. Konsumen akan diberatkan pada naiknya harga suatu produk yang dikenakan harga dasar tersebut sehingga mereka harus membayar lebih mahal. Sebaliknya, dari sisi produsen atau pun supplier, mereka akan mendapatkan jaminan atas harga yang lebih tinggi dari sebelumnya, sehingga ada keamanan untuk meningkatkan kapasitas produksi. (2) Penetapan Harga Maksimum (ceiling price). Harga maksimum merupakan perubahan tertinggi yang diperbolehkan terhadap suatu harga barang yang telah ditetapkan dalam suatu kontrak dalam suatu masa perdagangan sesuai dengan aturan perdagangan yang ada. Harga pasar yang terkena harga maksimum tidak diperbolehkan untuk menaikkan harga di atas harga maksimum yang telah ditetapkan. Kebijakan harga maksimum biasanya diberlakukan pada saat harga pasar yang ada tidak mengalami kenaikan yang cenderung berarti dalam kurun waktu yang singkat sedangkan suatu permintaan pasar terhadap produk meningkat. hal ini akan memicu produsen atau supplier untuk menaikkan harga. Dalam situasi seperti ini kebijakan harga maksimum perlu diberlakukan untuk menjaga stabilitas harga pasar supaya kenaikan harga yang ditetapkan oleh produsen tidak terlalu tinggi dan tidak membebani produsen. Contoh ceiling price ini adalah penetapan harga obatobatan di apotek, harga BBM, dan tarif angkutan atau transportasi seperti tiket bus 
kota, tarif kereta api dan tarif taksi per kilometer.

Kedua, Intervensi Pemerintah tidak Langsung: (1) Penetapan Pajak. Kebijakan penetapan pajak dilakukan oleh pemerintah dengan cara mengenakan pajak yang berbedabeda untuk berbagai komoditas. Misalnya untuk melindungi produsen dalam negeri, pemerintah dapat meningkatkan tarif pajak yang tinggi untuk barang impor. Hal tersebut menyebabkan konsumen membeli produk dalam dalam negeri yang harganya relatif lebih murah. (2) Pemberian subsidi. Pemerintah dapat melakukan intervensi atau campur tangan dalam pembentukan harga pasar yaitu melalui pemberian subsidi. Subsidi biasanya diberikan pemerintah kepada perusahaan-perusahaan penghasil barang kebutuhan pokok. Subsidi juga diberikan kepada perusahaan yang baru berkembang untuk menekan biaya produksi supaya mampu bersaing terhadap produkproduk impor. Kebijakan ini ditempuh pemerintah dalam upaya pengendalian harga untuk melindungi produsen maupun konsumen sekaligus untuk menekan laju inflasi.

\section{Peran Pemerintah Dalam Menentukan Nilai Tukar Barang Menurut Islam}

Dalam sejarah Islam masalah penentuan harga dibebaskan berdasarkan persetujuan khalayak masyarakat. ${ }^{21}$ Rasulullah sangat menghargai harga yang terjadi, karena mekanisme pasar yang bebas dan menyuruh masyarakat muslim untuk mematuhi peraturan ini. Beliau menolak untuk membuat kebijakan penetapan harga manakala tingkat harga di Madinah pada saat itu tiba-tiba naik. Sepanjang kenaikan terjadi karena kekuatan permintaan dan penawaran yang murni dan wajar, yang tidak dipaksa atau tekanan pihak tertentu (tekanan monopilistik dan monopsonistik), maka tidak ada alasan untuk tidak menghormati harga pasar. Khalifah Umar bin Khattab juga melarang mematok harga karena Rasulullah SAW melarang mamatok harga. Diriwayatkan oleh Ashhabus Sunan, dari Anas ra., ia berkata : "orang-orang bertanya kepada Rasulullah SAW, wahai Rasulullah SAW, harga semakin melambung tinggi, maka hendaknya tuan mematok harga untuk kami”. Maka Rasulullah menjawab : "sesungguhnya

\footnotetext{
${ }^{21}$ Lukman Hakim, Prinsip-Prinsip, h. 177
}

Allahlah yang maha menentukan harga, yang menggenggam dengan tidak memberi, yang memberi, yang mengaruniai rejeki, sesungguhnya akau berharap agar Allah yang memberi (patokan), dan bukan salah seorang diantara kalian yang memintaku agar aku berbuat dzalim baik terhadap darah (nyawa) maupun hart benda."

Meskipun Khalifah Umar tidak menetapkan harga, tetapi beliau seringkali menginspeksi pasar dan menanyakan kepada orang-orang terdekatnya perihal harga-harga yang ada di pasar. Ini menunjukkan adanya pengawasan oleh pemerintah terhadap perkembangan harga pasar. Dengan demikian tingkat harga dianggap sebagai indikasi terbesar tingkat matapencaharian, karena dia mempunyai pengaruh terhadap nilai mata uang. ${ }^{22} \mathrm{Bu}$ ahkan naiknya harga merupakan indikasi terbesar naiknya inflasi, dimana ketika terjadi inflasi, harga-harga meningkat dengan tajam. Hal tersebut menyebabkan berkurangnya nilai mata uang. Inflasi merupakan penyakit ekonomi yang berbahaya yang bisa menghalangi langkah pertumbuhan ekonomi atau memberhentikan sama sekali langkah tersebut.

Tas'iir adalah membatasi harga di pasaran, tidak boleh menjual dengan diluar harga yang telah ditetapkan. Ada dua macam tas'iir: (1) Bila harga di pasaran dibatasi dengan zalim. Padahal pedagang menjual dengan harga yang wajar. Kalaupun terjadi kenaikan harga, maka itu terjadi karena keterbatasan stok atau karena besarnya demand (permintaan). Membatasi harga dalam kondisi ini termasuk bentuk kezaliman karena ada paksaan tanpa jalan yang benar. Dalam hadis Anas bin Malik disebutkan: "Sesungguhnya Allah yang pantas menaikkan dan menurunkan harga, Dialah yang menahan dan melapangkan rizqi. Aku harap dapat berjumpa dengan Allah dan tidak ada satupun dari kalian yang menuntutku karena kezaliman pada darah dan harta. ${ }^{23}$ (2) Bila harga barang dibatasi di pasaran dengan adil. Pembatasan harga disini terjadi ketika masyarakat sangat butuh dengan barang tersebut, lalu barang dijual dengan harga yang tinggi dan tidak masuk akal. Maka pemerintah punya

\footnotetext{
${ }^{22}$ Lukman Hakim, Prinsip-Prinsip, h. 173

${ }^{23}$ HR. Abu Dawud no. 3451, Tirmidzi no. 1314, Ibnu Majah no. 2200
} 
wewenang di pasar membatasi harga supaya tidak melonjak tinggi. Pembatasan disini bertujuan untuk tidak menyusahkan masyarakat lantaran kenaikan harga kebutuhan pokok mereka. Dibatasilah dengan harga tertentu, sehingga pelaku usaha harus menjual dengan harga semisal itu. Tatkala harga dibatasi demikian, maka wajib diikuti.

Ali bin Abi Thalib pernah berkeliling menginspeksi pasar Kuffah dengan membawa tongkat pemukul seraya berkata : "Wahai segenap pedagang, ambillah yang benar, niscaya kamu selamat. Jangan kamu tolak keuntungan yang sedikit, karena dengan menolaknya kamu akan terhalang untuk mendapatkan yang banyak".

Sikap Umar bin Khattab dan Ali bin Abi Thalib ini menunjukkan pentingnya pengawasan terhadap pasar, mengawasi dan mengendalikan mekanisme pasar dan menghilangkan distorsi yang terjadi. Intervensi pasar sangat penting dalam menjamin barang kebutuhan pokok. Dalam keadaan kekurangan barang kebutuhan pokok, pemerintah dapat membuat aturan supaya pedagang yang menahan barangnya untuk dijual ke pasar. Dalam hal ini, bila perlu pemerintah harus mempunyai harga logistik guna menjaga agar pelaku usaha dan konsumen tidak dirugikan oleh naik dan turunnya harga secara ekstrim.

\section{Simpulan}

Berdasarkan Pasal 1320 KUH Perdata, maka kesepakatan mengenai harga dapat diartikan sebuah perjanjian yang harus disepakati antara pelaku usaha dan konsumen. Maka harga yang dimaksud dalam pasal 4 huruf c UU nomor 8 Tahun 1999 Tentang Perlindungan Konsumen adalah harga yang disepakati oleh kedua belah pihak. Pasal 1338 KUH Perdata menyiratkan

\section{DAFTAR PUSTAKA}

\section{Perundangan :}

UU nomor 8 tahun 1999 tentang Perlindungan Konsumen

\section{Buku :}

Ali, Zainuddin, Hukum Ekonomi Syariah, (Jakarta : Sinar Grafika, 2008)

Hakim, Lukman, Prinsip-Prinsip Ekonomi Islam (tanpa tempat : Erlangga, 2012) bahwa kesepakatan ini haruslah berdasarkan atas itikad baik, sehingga menentukan harga yang terlalu tinggi dapat dikatakan tidak beritikad baik atau tidak sesuai dengan pasal 1338 KUH Perdata. Harga yang telah disepakati ini adalah sah jika penyesatan, penipuan dan pemaksaan. ada unsur ( $d$ wang, dwaling, bedrog).

Mengenai nilai tukar barang atau harga, Islam sesungguhnya tidak memberikan batasan yang pasti berapa keuntungan yang boleh diambil oleh pelaku usaha, asal dari mencari keuntungan itu disyariatkan, kecuali apabila dilakukan dengan cara-cara yang bertentangan dengan syara'. Soal keuntungan dalam usaha bisnis ini tidak ada standarisasinya, baik bersifat minimal maupun maksimal.

Penetapan harga pada dasarnya diserahkan kepada mekanisme pasar, kecuali jika terdapat distorsi atau penyimpangan yang mempengaruhi harga pasar. Dalam hal ini pemerintah harus melakukan pengawasan, kontrol harga atau intervensi sehingga harga kembali normal. Intervensi pemerintah dalam penetapan harga ini dilakukan melalui dua cara yaitu intervensi secara langsung yang dilakukan dengan menetapkan harga minimum (floor price) dan harga maksimum (ceilling price) sedangkan intervensi tidak langsung dilakukan dengan membuat kebijakan di bidang perpajakan dan subsidi.

Dalam sejarah Islam diceritakan bahwa Umar bin Khattab dan Ali bin Abi Thalib sering melakukan inspeksi pasar. Hal demikian menunjukkan bahwa pengawasan harga di pasar harus selalu dikontrol atau diawasi oleh pemerintah, sehingga ketika terjadi penyimpangan akan dilakukan tindakan dengan segera sebelum terjadi akibat yang signifikan seperti terjadinya inflasi.

Kadir, A., Hukum Bisnis Syariah Dalam AlQuran (Jakarta : Sinar Grafika Offset, 2010)

Lubis, Suhrawardi K dan Wajdi, Farid, Hukum Ekonomi Islam (Jakarta : Sinar Grafika Offset, 2012)

Miru, Ahmad dan Yodo, Sutarman, Hukum Perlindungan Konsumen, (Jakarta : PT Raja Grafindo Persada, 2007) 
Iffaty Nasyi’ah, Prinsip Keadilan dan keseimbangan...| 127

Qardlawi, al, Yusuf, Fatwa-Fatwa Kontemporer 2 (Hadyu al-Islam; Fatawi Muasyirah), penerjemah As'ad Yasin (Jakarta : Gema Insani Press, 1995)

Rivai, Veithzal, dkk., Islamic Business And Economic Ethics, Mengacu Pada alQur'an dan mengikuti jejak Rasulullah SAW dalam Bisnis, Keuangan dan
Ekonomi (Jakarta : PT Bumi Aksara, 2012)

Zulham, Hukum Perlindungan Konsumen (Jakarta : Prenada Media Group, 2013)

WEB :

Satrio, Sigit. Penetapan Harga (Ceiling Price dan Floor Price) (Online), (http://satriasig.blogspot.com/2011/11/penetapan-harga-ceilingprice-dan-floor.html. Diakses 18 Mei 2014) 